\title{
Broadening our vision
}

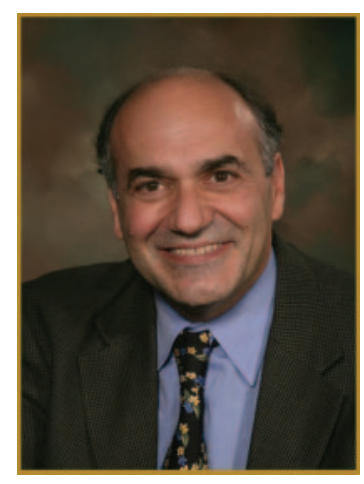

Richard Barbano, MD, PhD

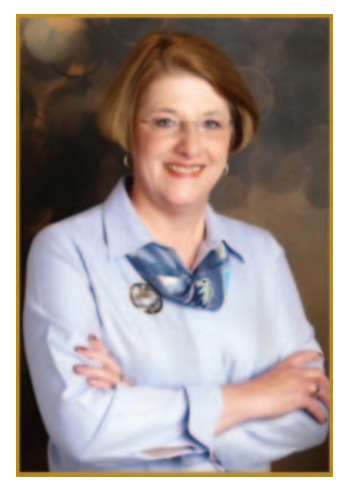

Laura Powers, MD

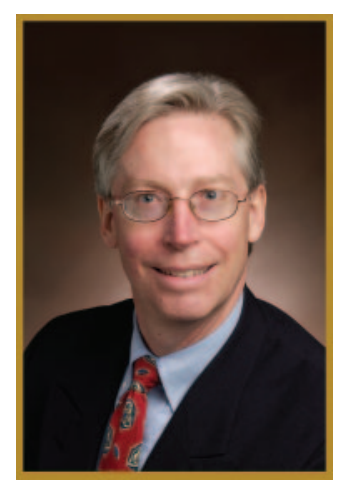

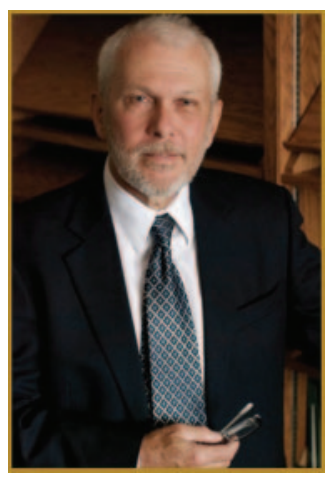

David Anderson, MD

I am thrilled to announce the expansion of the Neurology: Clinical Practice Team. After a competitive search, Richard L. Barbano, MD, PhD, FAAN; Laura B. Powers, MD, FAAN; and David C. Anderson, MD, FAAN were selected as Associate Editors in January 2012. Their enthusiasm and varied backgrounds are helping us broaden our vision.

Richard Barbano's experience engenders his multifaceted perspective. His background as educator, clinician, and administrator attests to and informs us on the breadth of the neurology profession. Dr. Barbano serves as Professor of Neurology at the University of Rochester, is an attending neurologist at Strong Memorial Hospital, and is Chief of Neurology and Chief of Physical Medicine \& Rehabilitation at Rochester General Hospital. He also serves on the American Academy of Neurology's (AAN) Guideline Development Subcommittee.

Laura Powers solidly grounds us in practice. Retired from active neurology practice in Knoxville, TN, she has participated in numerous committees with a practice focus, including the Medical Economics and Management Committee and the Practicing Physicians Advisory Council to Medicare. Dr. Powers has served on the AAN's Board of Directors, is the AAN's representative to the ICD-9-CM Coordination and Maintenance Committee, and was recently appointed Associate Editor for Coding for Continuum: Lifelong Learning in Neurology ${ }^{\circledR}$. 
David Anderson provides us a general neurology viewpoint. Initially trained in internal medicine, he shifted his focus to neurology under A.B. Baker at the University of Minnesota (UMN). Dr. Anderson practices general neurology, with special interests in stroke and medical education, at Hennepin County Medical Center (HCMC) and UMN. He served as chief of neurology at HCMC and, until recently, head of neurology at UMN. He has also chaired the Residency Review Committee for Neurology for the Accreditation Council for Graduate Medical Education and the Accreditation Council of the United Council for Neurological Subspecialties.

At our first face-to-face editorial meeting held at the AAN's annual meeting in New Orleans, we explored how to integrate podcasts, how best to partner with guidelines initiatives, how we might make statistics useful to the neurology practitioner, and how to implement a rapid correspondence section akin to Neurology's successful WriteClick $^{\mathrm{TM}}$ initiative. We also discussed expanding the journal's offerings to include new manuscript categories (e.g., Book Reviews), incorporating CME for our readers, and reaching out to the practice community.

We continue to encourage submissions, especially those from our international readers. Look at future issues for articles specifically geared toward understanding health care differences throughout the world.

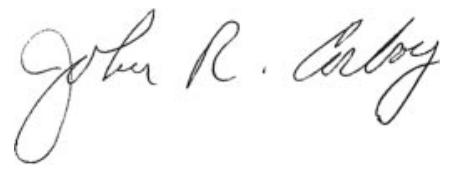

John R. Corboy, MD, FAAN 


\section{Neurology ${ }^{\circ}$ Clinical Practice}

Broadening our vision

John R. Corboy

Neurol Clin Pract 2012;2;89-90

DOI 10.1212/CPJ.0b013e31825adc6c

This information is current as of June 11, 2012

$\begin{array}{ll}\begin{array}{l}\text { Updated Information \& } \\ \text { Services }\end{array} & \begin{array}{l}\text { including high resolution figures, can be found at: } \\ \text { http://cp.neurology.org/content/2/2/89.full.html }\end{array} \\ \text { Subspecialty Collections } & \begin{array}{l}\text { This article, along with others on similar topics, appears in the } \\ \text { following collection(s): } \\ \text { All Practice Management } \\ \text { http://cp.neurology.org//cgi/collection/all_practice_management }\end{array} \\ & \begin{array}{l}\text { Information about reproducing this article in parts (figures,tables) or in } \\ \text { its entirety can be found online at: } \\ \text { http://cp.neurology.org/misc/about.xhtml\#permissions } \\ \text { Information about ordering reprints can be found online: } \\ \text { http://cp.neurology.org/misc/addir.xhtml\#reprintsus }\end{array} \\ & \end{array}$

Neurol Clin Pract is an official journal of the American Academy of Neurology. Published continuously since 2011, it is now a bimonthly with 6 issues per year. Copyright Copyright $\odot 2012$ by AAN Enterprises, Inc.. All rights reserved. Print ISSN: 2163-0402. Online ISSN: 2163-0933.

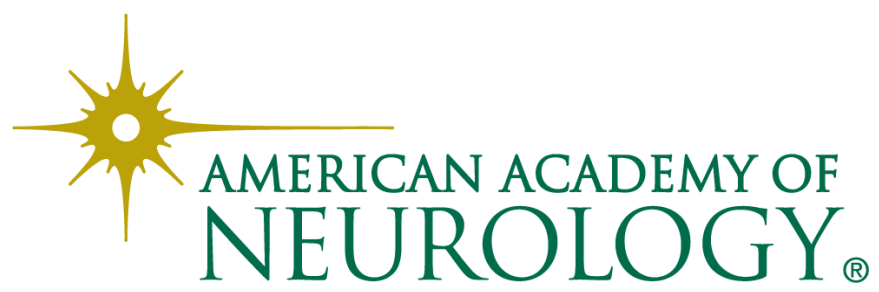

